\section{Academy to stand alone}

\section{Moscow}

WiTH a surprise decree, President Mikhail Gorbachev has declared the Soviet Academy of Sciences a self-governing organization working on the basis of Soviet law and its own statutes.

Now, no state, party or other organization will have a right to interfere in the affairs of the academy, which will own all the fixed assets under its control, including institutes, laboratories and enterprises. State financing of the academy's research will continue, but the decree requires the results to be transferred to the state under appropriate copyright arrangements.

The granting of independence to the academy and its separation from the government was welcomed by Academician Yuri Osipyan, an academy vice-president and a member of the presidential council. He says that, in the past, the USSR Council of Ministers has unduly influenced the academy's management. (The same might be said of the Central Committee of the Party.) Often, as in the suppression of genetics and cynbernetics, and in the criticism of "wilful" scientists for elitism, the academy has been over-obedient to higher authorities.

The academy is now freed from administrative bonds, but is faced with the challenge of how to use its independence.

The decree has nevertheless met with a mixed response from the scientific community, at least in part because there had been no prior discussion of it. Some fear that the decree will entrench the monopoly of the academy in research and confirm in its present position a management now much criticized from below. There are also fears that the democratization of the academy will be impeded.

Some also ask whether the hidden purpose of the decree is to prevent academy institutes on the territory of the Russian Federation from falling into the hands of the proposed Russian Academy of Sciences, which has been much discussed in the Soviet press. Alone among the republics of the Soviet Union, the Russian Federation anachronistically lacks an academy of its own.

There is powerful support for the founding of a Russian academy. In an interview, Nicolai Laverov, chairman of the USSR State Committee for Science and Technology and vice-chairman of the USSR Council of Ministers, said that "there must certainly be a Russian academy, but not at the cost of the destruction of the all-union academy".

Laverov nevertheless believes that there are several strong institutes on Russian soil that could be the foundation of a Russian academy, carrying out fundamental studies and dealing with specific republic problems. He notes that the new decree refers to an all-union research fund from which studies by republic academies will be supported when they are part of a national plan. The proposed Russian academy, he says, should have the special task of engaging in the research enterprise scientists now working in higher education.

The proposed research fund is an important innovation. According to Laverov, Both the Soviet Union (with the consent of the Supreme Soviet of the USSR) and the union republics will contribute to it. There will be a governing council representing the union and republic academies, Laverov's state committee and higher education and industrial institutes engaged in basic research, which means that academy institutes will not be the only beneficiaries. Laverov says that there will also be target-orientated funds for the support of research.

Laverov does not rule out the possibility that some republics will refuse to contribute to this all-union research organization. Some of them, he acknowledges, will find it difficult to contribute, for which reason the general budget of the Soviet Union (based on taxation of enterprise profits) will remain the foundation of fundamental research.

But many academy scientists are worried by the money problem. The capacity of the centre to finance research will depend on the power it retains under the union treaty now being negotiated.

Meanwhile, the presidential decree will offer all-union scientists a pay rise as well as a contract system of employment, both within the Soviet Union and abroad. These provisions seemed to have been prompted by the expected law on free emigration from the Sovit Union, and the potential brain drain that may follow. Poor equipment and working conditions, and miserably low pay, are forcing the more talented young researchers to think of leaving for research centres in the West.

Laverov says the emigration law will certainly bring "major difficulties" for science, which is why the new decree offers means by which the living and working conditions of academy staff may be improved. He says that the contract system should allow for faster promotion and the timely recognition of talented scientists. He notes that the contract system will impose obligation on scientists as well as employing organizations.

"Nobody particularly intends to create obstacles for Soviet scientists to work abroad", he says, "but the contract system is meant to ensure civilized conditions for the process". It will also regulate the work of foreign researchers at institutes of the Soviet academy.

Yuri Kanin

Novosti, Moscow

\section{Death strip becomes nature preserve \\ Munich}

DESPITE its legendary lack of concern for the environment, the former Communist regime in East Germany did inadvertently create one massive nature reserve - the 600-km-long, 5-km-wide 'death strip' that separated East and West Germany. The strip, and the huge hunting estates kept by Communist party bosses, provided a safe home for rare species of cranes, storks, whitefish and wild flowers. But peace and prosperity are now threatening these creatures and their habitats as prosperous West German tourists pour over the border into East Germany.

Environment officials in both parts of Germany have responded with a controversial attempt to create nature preserves along the former border. West German Environment Minister Klaus Töpfer declares that the the "green belt" along the border is "the only positive thing to emerge from the division of Germany". But residents complain that the creation of parks will continue the isolation imposed by the impossiblity of crossing the 'death strip'. The mayor of the East German village of Lassahn protested to the West German newspaper Frankfurter Rundschau, "Why should we drive 90 kilometres to the next town when it is only 12 kilometres away?" A spokeswoman at the Bonn Environment Ministry says that, since the borders opened, thousands of tourists from both parts of Germany have picnicked and hiked all over the more popular border areas such as the Brocken in the Harz Mountains. Although Bonn does not plan to stop them from going there altogether, "we are afraid that the tourists will soon trample everything into the ground" if the government does not step in soon.

The black stork Ciconia nigra and the crane Grus grus are endangered by unification, says Knut Haarmann of the West German Research Centre for Nature Protection in Bonn. Only through the efforts of ecologists, who have erected protective shelters in remote areas, have $\mathbf{5 0}$ breeding pairs survived. But many hundred pairs of each exist in East Germany.

Huge collective farms dotted with uncultivated, swampy patches, which are ideal for breeding and the raising of young, have also contributed to the survival of black storks and cranes in East Germany, says Haarmann.

It will be up to the Länder (states), not the federal government, to create nature preserves in the areas in question, but Fritz Dieterich of the Bonn environment ministry said that Bonn will go as far as possible to coordinate such efforts. Although not every area may be protected, he says, "on a large scale, I predict we will succeed". Steven Dickman 